\title{
Corrosion Characteristics of Reinforced Concrete Under the Coupled Effects of Chloride Ingress and Static Loading: Laboratory Tests and Finite Element Analysis
}

\author{
Yidong XU *, Jiansheng SHEN, Yingying ZHENG, Jianghong MAO, Ping WU \\ School of Civil Engineering \& Architecture, Ningbo Institute of Technology of Zhejiang University, Ningbo, 315100, \\ China \\ crossref http://dx.doi.org/10.5755/j01.ms.24.2.17963
}

Received 15 April 2017; accepted 19 July 2017

\begin{abstract}
The aim of this paper is to describe the coupled effects of chloride ingress and static loading on the evolution of corrosion of steel reinforcement in concrete. A new corrosion test was adopted to accelerate the non-uniform corrosion of the steel. Finite element analysis was used to investigate the influence of coupled chemo-mechanical processes on corrosion expansion stress of the concrete cover. As is shown by the results, the half-cell potentials of steel reinforcement in the reinforced concrete specimens decreased with increase in the number of wetting-drying cycles and the applied static loading, which cause the steel reinforcement to be more prone to corrosion attack. Owing to the coupled action of chloride ingress and static loading, non-uniform distribution of corrosion activity on the steel reinforcement increased significantly. The finite element simulations showed the existence of static loading increased the maximum stress on the concrete cover, which increases the susceptibility of concrete cover to corrosion-related expansion cracking.

Keywords: chloride, static loading, coupled effect, non-uniform corrosion, finite element.
\end{abstract}

\section{INTRODUCTION}

The deterioration of reinforced concrete (RC) structures due to the corrosion of steel reinforcement is one of the most critical durability concerns in the world [1-3]. The volume expansion of corrosion product leads to the existence of tensile stress in the concrete around the steel reinforcement, which causes the cracking of concrete cover and reduces the durability of the RC structure.

Considerable research work has been carried out on the corrosion evolution of steel reinforcement in RC structures. Zhao $[4,5]$ adopted nano-indentation techniques to determine the elastic moduli of corrosion products. A Gaussian function was used to model the distribution of the non-uniform corrosion. Khan [6] investigated the evolution of steel reinforcement corrosion in comparison to corrosion crack width in a highlycorroded RC beam. The experimental results were compared with existing models established by Rodriguez [7], Vidal [8] and Zhang [9]. With the rapid development of numerical simulation techniques, finite element analysis (FEA) has been widely used to simulate concrete cover cracking due to steel reinforcement corrosion [10]. Guzmán [11] adopted an embedded cohesive crack 2D finite element to simulate the cracking process of concrete cover. By considering the influences of concrete heterogeneities and the porous layer generated at the rebar/concrete interface on the failure patterns, Du [12] and Jin [13] established a meso-scale mechanical model and method for the study on the failure behavior of concrete cover. A non-uniform radial displacement distribution was

\footnotetext{
* Corresponding author. Tel.: +86-574-88229132

E-mail address: xyd@nit.zju.edu.cn (Y.Xu)
}

adopted to simulate the corrosion expansion behavior of the rebar.

The above-mentioned studies, however, focused mainly upon the effects of chloride attack, yet the coupled chemo-mechanical effect on the steel reinforcement corrosion has not been thoroughly considered apart from a few exceptions $[14,15]$. The present paper describes the corrosion characteristics of reinforced concrete under the coupled effects of chloride attack and static loading, based on the findings from laboratory tests and numerical simulation calculations. A new corrosion test was adopted to accelerate non-uniform corrosion of steel reinforcement in the concrete. In order to reflect the effect of applied static loading on steel reinforcement corrosion, the halfcell potential and the degree of corrosion of the steel reinforcements were measured. In particular, the investigation studied whether there was any difference in the corrosion characteristics of the steel reinforcement under chloride ingress and under the coupled effect of chloride attack and static loading. Finite element analysis (FEA) was used to model the effects of non-uniform corrosion-induced damage of reinforced concrete under coupled chemo-mechanical action. The non-uniform corrosion expansion of steel reinforcement in the finite element model was simulated by using the thermal expansion method.

\section{CORROSION CHARACTERISTICS OF STEEL REINFORCEMENTS IN RC BEAM UNDER DIFFERENT WORKING CONDITIONS}

\subsection{Materials}

The cement used was Type 42.5 Portland cement according to Chinese Standards GB175 "Common 
Portland Cement". The fine aggregate used was river sand. The coarse aggregate used was natural gravel with a maximum diameter of $20 \mathrm{~mm}$. The mix proportion of the concrete is shown in Table 1 and the designed concrete compressive strength (measured on cubes) was $30 \mathrm{MPa}$. Hot rolled plain steel bar of type HPB235 (with nominal diameter of $10 \mathrm{~mm}$ ) was used as reinforcement. The size of the RC beam was $100 \mathrm{~mm} \times 100 \mathrm{~mm} \times 500 \mathrm{~mm}$ with a cover thickness of $20 \mathrm{~mm}$. A piece of stainless steel sheet was placed in the centre of the specimen to act as the cathode in the accelerated corrosion tests, as shown in Fig. 1. The rust-removal solution was prepared by mixing 3 parts by mass of hexamethylene tetramine in 97 parts of diluted hydrochloric acid.

Table 1. Mix proportion of the concrete, $\mathrm{kg} / \mathrm{m}^{3}$

\begin{tabular}{|c|c|c|c|}
\hline Portland cement & Water & Fine aggregate & Coarse aggregate \\
\hline 365 & 192 & 730 & 1095 \\
\hline
\end{tabular}

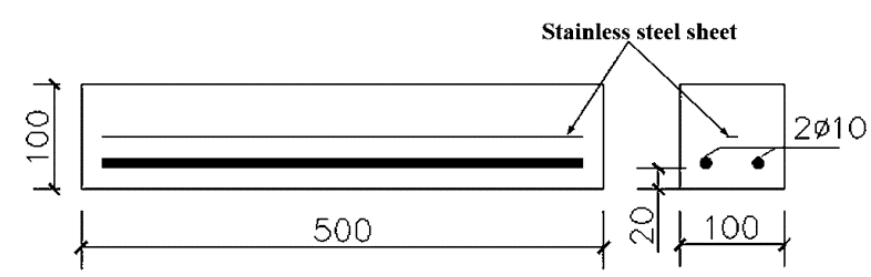

Fig. 1. Details of the tested RC specimen

\subsection{Test procedures}

RC beams under chloride attack, (specimens denoted as BMC), and under the coupled effects of chloride ingress and static loading, (specimens denoted as BMCL), were prepared. After curing in a fog room $\left(20 \pm 2{ }^{\circ} \mathrm{C}, 95 \%\right.$ relative humidity) for 28 days, the specimens were demolded and then used for the accelerated corrosion tests.

For RC structures, the corrosion of steel reinforcement is often attributable to chloride attack, which is "localized" non-uniform corrosion. In order to simulate the nonuniform corrosion of steel reinforcement in concrete under chloride attack, a new accelerated corrosion test was adopted for this study, which can be considered in two steps, namely, (1) the electro-migration step and (2) the wet-dry cycle step [16]. Fig. 2 shows a schematic of the accelerated corrosion test of an RC beam under chloride ingress. A sponge, which soaks up the $\mathrm{NaCl}$ solution, was used to keep the concrete wet and a stainless steel net was attached to the sponge. The outside of the RC beam was then wrapped with a plastic sheet to keep the moisture in the sponge.

Firstly, the sponge was soaked with $5 \% \mathrm{NaCl}$ to make the BMC specimen moist for more than $24 \mathrm{~h}$. Then, the stainless steel sheet embedded in the BMC specimen was connected to the anode of a DC power source while the cathode of the DC power source was connected to the stainless steel net. A constant voltage of $30 \mathrm{~V}$ was applied, as a result of which, the chloride ions were migrated into concrete cover under the action of the electric field. After that, a typical accelerated electrochemical corrosion test was conducted. The steel reinforcement embedded in the $\mathrm{RC}$ beam was connected to the anode of a DC power source while the cathode of the DC power source was still connected to the stainless steel net. Finally, a wet-dry cycle was conducted immediately after the electro-migration step. Each cycle involved 3 days drying and 4 days wetting. During the wetting process, a current density of $200 \mu \mathrm{A} / \mathrm{cm}^{2}$ was applied in order to accelerate the corrosion process.

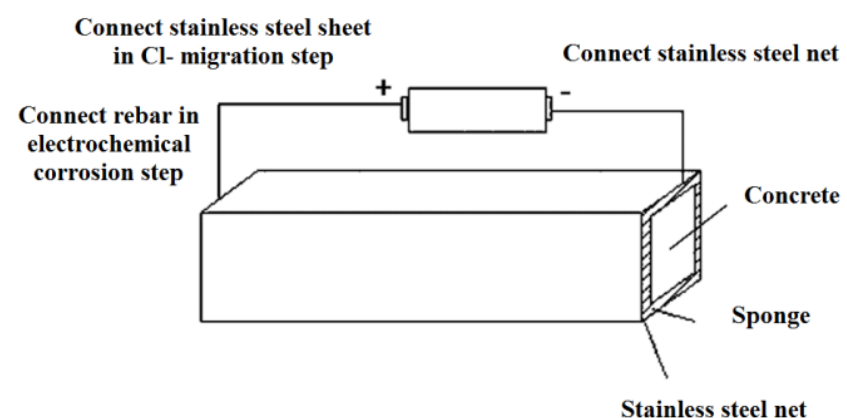

Fig. 2. Schematic illustration of accelerated corrosion test of RC beam under chloride ingress

In order to reflect the coupled effect of chloride ingress and static loading on RC beam, two BMCL specimens were loaded during the accelerated corrosion test by using a self-equilibrium loading frame. The loading system was composed of a pressure transducer, loading bolts, nuts, springs and a loaded steel base plate, as shown in Fig. 3. The magnitude of the ultimate bearing capacity of the RC beam was $29 \mathrm{kN}$, which was calculated following the Chinese Standard GB50010 "Code for Design of Concrete Structures". The magnitudes of the applied loads were $30 \%$ and $50 \%$ of the ultimate bearing capacity respectively. The two RC beams were denoted as BMCL-30 and BMCL-50.

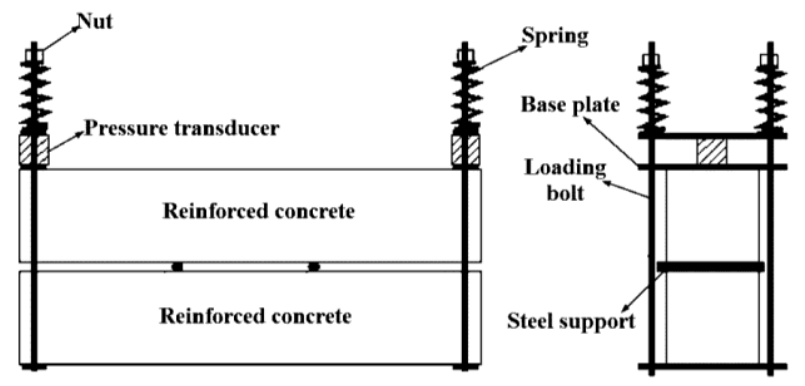

Fig. 3. Schematic illustrations of the loading frame

Half-cell potential measurement is widely adopted as a non-destructive technique to obtain a qualitative indication of the corrosion behaviour of steel reinforcement in concrete structures $[17,18]$. When every wetting-drying cycle test was completed, the half-cell potential of the steel reinforcement in the RC beam was checked using a HalfCell 200 Concrete Rebar Corrosion Tester. The criteria of corrosion probability are shown in Table 2.

Table 2. Criterion for corrosion probability of steel reinforcement in concrete

\begin{tabular}{|c|c|}
\hline Half-cell potential, mV CSE & Corrosion probability \\
\hline$>-200$ & $<10 \%$ \\
\hline$-200 \sim-350$ & Uncertain \\
\hline$<-350$ & $>90 \%$ \\
\hline
\end{tabular}

After the accelerated corrosion tests, the steel reinforcements were removed from the concrete and were 
washed by using the rust removing solution to remove corrosion products, from which the corrosion mass loss ratio of the reinforcement was calculated. The corrosion mass loss ratio was calculated based on the original and final masses, as is shown in Eq. 1.

$$
S=\frac{m_{0}-m_{1}}{m_{0}} \times 100 \%,
$$

where $S$ is the corrosion mass loss ratio; $m_{0}$ is the mass of the uncorroded specimen $(\mathrm{g}) ; m_{1}$ is the mass of the corroded specimen after the de-rusting $(\mathrm{g})$.

The corrosion morphology images of the steel reinforcement were taken by using digital camera and the pictures obtained were stored as 24-bit colour JPEG format.

\subsection{Results}

The half-cell potentials of steel reinforcements under different working conditions are shown in Fig. 4. The halfcell potentials of all the three specimens were observed to decrease with increase in the number of wet-dry cycles. Furthermore, the coupled action of chloride ingress and static loading affected the half-cell potential significantly. After a wet-dry cycle, the half-cell potentials of all the three specimens were about $-300 \mathrm{mV}$, which meant that the probability of corrosion on the steel reinforcement was uncertain. However, after two wet-dry cycles, the half-cell potential of BMC was still approximately $-300 \mathrm{mV}$, while the half-cell potentials of BMCL-30 and BMCL-50 were all around $-350 \mathrm{mV}$. With the further increase of the number of cycles, the coupled effects of chloride ingress and static loading on the half-cell potentials were increasingly evident. This indicated that tensile stress did make the steel reinforcement more prone to corrosion.

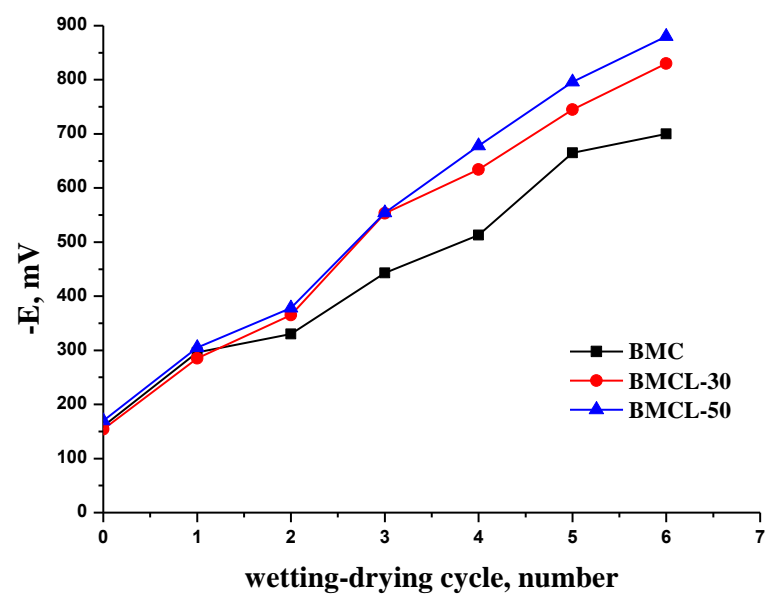

Fig. 4. Evolving change of the half-cell potentials

The three typical images of local corrosion morphology of steel reinforcement that are formed under different working conditions are shown in Fig. 5. It is observed from the figure that significant differences are present amongst the three specimens. Under chloride attack, some local corrosion pits were present on the surface of corroded bars. The size of corrosion pits was small and some of them were isolated, which indicated that the corrosion rate was not very high and the non-uniform distribution of the corrosion damage was relatively low.
While under the coupled effect of chloride ingress and static loading a large variety of local corrosion morphologies were generated on the surface of the corroded rebars. These corrosion morphologies generally had irregular shapes, sizes and orientations. Most of the local corrosion morphologies overlapped or were connected together. The degree of non-uniformity of corrosion morphology on the BMCL-50 was higher than that of the BMCL-30.

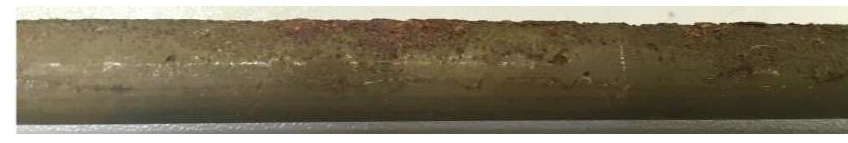

a

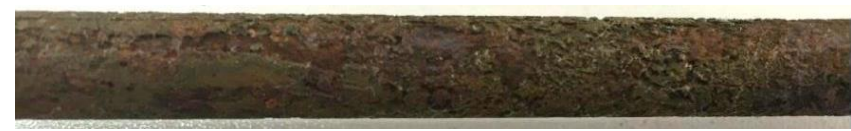

b

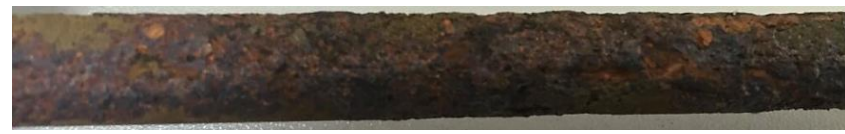

$10 \mathrm{~mm}$

Fig. 5. Corroded surface morphology of steel reinforcement under different service conditions: a-BMC specimen; b-BMCL-30 specimen; c-BMCL-50 specimen

Table 3 shows the corrosion loss mass ratio of steel reinforcement under different service conditions. Under chloride attack, the average value of corrosion loss mass ratio was $5.11 \%$ whereas under coupled conditions of chloride ingress and static loading the corrosion loss mass ratio of BMCL-30 and BMCL-50 were $5.80 \%$ and $6.23 \%$ respectively, which was higher than that for the BMC specimen. The average value of corrosion loss mass ratio increased with increase in the applied load, which indicates that the coupled chemo-mechanical process affected the degree of corrosion on the steel reinforcement.

Table 3. Corrosion loss mass ratio of steel reinforcement in RC specimens

\begin{tabular}{|c|c|c|c|c|}
\hline Code & $m_{0}, \mathrm{~g}$ & $m_{1}, \mathrm{~g}$ & $S$ & Average value of $S$ \\
\hline \multirow{2}{*}{ BMC } & 279.10 & 266.50 & $4.44 \%$ & \multirow{2}{*}{$5.11 \%$} \\
\cline { 2 - 4 } & 283.47 & 266.90 & $5.77 \%$ & \\
\hline \multirow{2}{*}{ BMCL-30 } & 304.88 & 288.00 & $5.47 \%$ & \multirow{2}{*}{$5.80 \%$} \\
\cline { 2 - 4 } & 279.04 & 261.75 & $6.12 \%$ & \\
\hline \multirow{2}{*}{ BMCL-50 } & 283.07 & 264.40 & $6.52 \%$ & \multirow{2}{*}{$6.23 \%$} \\
\cline { 2 - 4 } & 280.13 & 263.20 & $5.97 \%$ & \\
\hline
\end{tabular}

\subsection{Discussion}

The results mentioned above showed that the presence of a static load affected significantly the corrosion characteristics of the reinforcement. Indeed, previous work has shown that the pitting susceptibility and pitting potential of steel reinforcement was dependent on the type of load and the level of applied stress [19]. To evaluate if constant load can cause the corrosion potential of the carbon steel reinforcement to achieve less active values, 
analysis was carried out by Ortega [20] to establish if corrosion process on the reinforcements in concrete beams took place under tensile stress and the corrosion potentials were tested. The results demonstrated that the concrete cover cracking provided greater availability of oxygen to the steel reinforcement, increasing the formation of oxides and allowing the steel reinforcement to achieve more passive potentials. Besides, owing to the coupled action of chloride ingress and static loading, the corrosion pits tend to grow along the preferred orientation, which makes the corrosion pit pattern more angular and the non-uniform distribution of corrosion morphology on the reinforcement increases significantly [3].

\section{FINITE ELEMENT ANALYSIS OF NON- UNIFORM CORROSION-INDUCED DAMAGE IN REINFORCED CONCRETE}

For RC structures exposed to a marine environment the cracking of concrete cover often is caused by corrosion of the steel reinforcement. As was shown in Section 2, the coupled effect of chloride attack and static loading has a significant influence on the corrosion characteristics of steel reinforcement. The influence of coupled chemomechanical processes on the corrosion expansion stress of concrete cover has become a new focus for research. In this section, the use of finite element analysis is considered to investigate the issue.

\subsection{Finite element model}

Finite element analysis was carried out using ABAQUS software and the model used is shown in Fig. 6. The size of finite element model was $100 \mathrm{~mm} \times 100 \mathrm{~mm} \times 500 \mathrm{~mm}$, which was identical to the tested RC specimen shown in Fig. 1. The cover thickness was $20 \mathrm{~mm}$ and the diameter of steel reinforcement was $10 \mathrm{~mm}$. The mesh was created using hexahedral elements C3D8R, which were 8-node brick elements with reduced integration. A fine mesh was used in the lower part of the model in order to achieve accurate results. The material parameters used in the FEA study are shown in Table 4.

Table 4. The material parameters adopted in numerical simulation

\begin{tabular}{|c|c|c|}
\hline Material & Young's modulus, GPa & Poisson's ratio \\
\hline Concrete & 27 & 0.21 \\
\hline Steel reinforcement & 200 & 0.30 \\
\hline
\end{tabular}

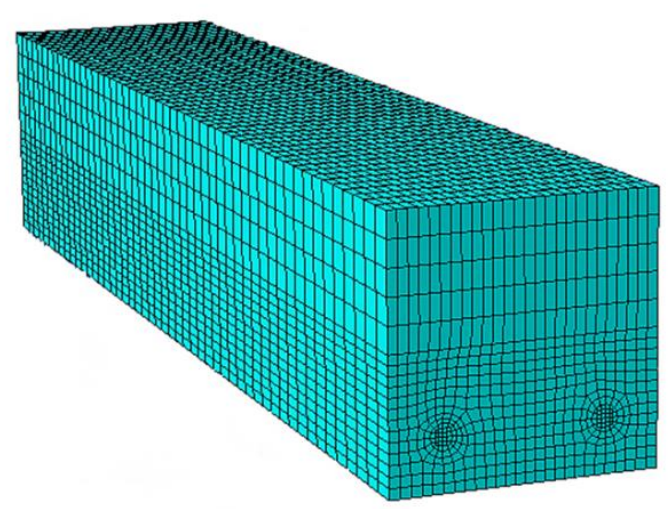

Fig. 6. Finite element model
The non-uniform corrosion expansion of steel reinforcement was simulated by using a thermal expansion method, which was controlled by the temperature increment of the steel reinforcement (denoted as $\Delta T$ ). In this paper, $\Delta T$ was adopted as $60^{\circ} \mathrm{C}$ and the linear expansion coefficient of steel reinforcement was assumed to be $1.2 \times 10^{-5} /{ }^{\circ} \mathrm{C}$.

When the steel reinforcement is heated, concrete cover will deform under the action of the thermal expansion. Owing to the relatively thin concrete cover around the corner reinforcements, the concrete cover produces nonuniform deformation, as is shown in Fig. 7. It can be observed from the figure that the deformation of concrete cover is similar to the effect of non-uniform corrosion expansion in an RC structure. Therefore, the thermal expansion method can be used to simulate the effect of rust jacking though in the process of numerical simulation, the bond damage between steel reinforcement and concrete cover is not considered.

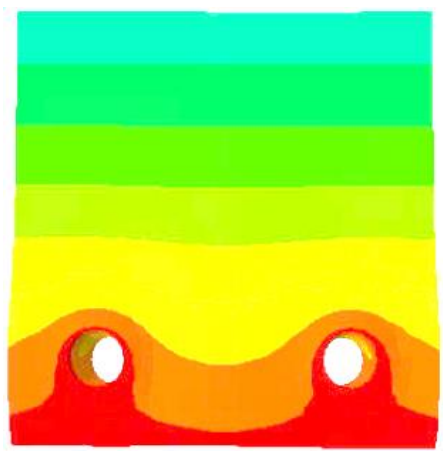

Fig. 7. Deformation of concrete cover under the action of thermal expansion

In order to simulate the coupled action of corrosion expansion and static loading, the specimens were loaded using the four-point bending method, as is shown in Fig. 8. A total of three sets of models, which corresponded to specimens BMC, BMCL-30 and BMCL-50, were established, as are listed in Table 5.

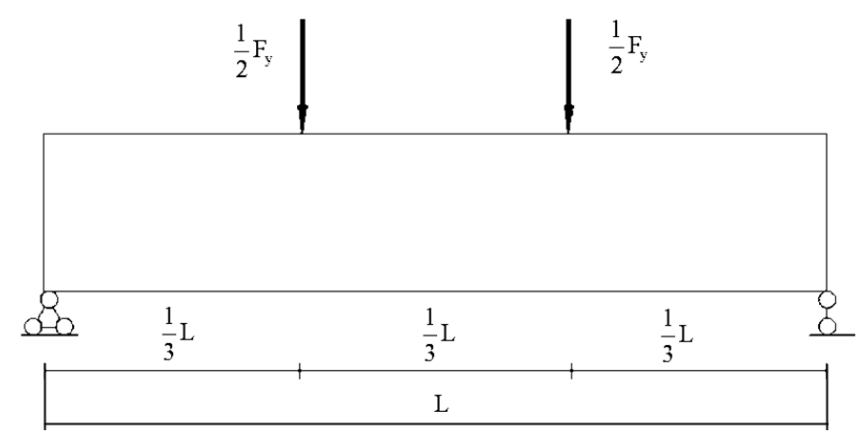

Fig. 8. Schematic illustration of the four-point bending method

Table 5. The models employed for FEA

\begin{tabular}{|c|c|c|c|}
\hline Model code & Corresponding specimen & $\mathrm{F}_{\mathrm{y}}, \mathrm{kN}$ & $\Delta T,{ }^{\circ} \mathrm{C}$ \\
\hline Model-A & BMC & 0 & 60 \\
\hline Model-B & BMCL-30 & 8.7 & 60 \\
\hline Model-C & BMCL-50 & 14.5 & 60 \\
\hline
\end{tabular}

\subsection{Results}

Fig. 9 shows the stress nephogram obtained from FEA based on Table 5. For Model-A, the coupled action of 
corrosion expansion and static loading was not considered. Damage sustained by the concrete cover is induced only by steel reinforcement expansion. As is shown by Fig. 9 a, the non-uniform distribution of the corrosion expansion (i.e. oxide jacking) force was relatively low, which was consistent with the results of the laboratory tests. The maximum stress in the concrete cover was $5.05 \mathrm{MPa}$, while for Model-B and Model-C, the coupled effects of steel reinforcement corrosion and static loading leads to significant non-uniform distribution of corrosion expansion, as is shown in Fig. 9 b and c. The most severely damaged section lay in the middle of the models, which are the 'pure bending' section of the models with the maximum bending moment. The maximum stress of concrete cover increased with the increase in applied static load. Compared to the maximum stress of Model-A, the maximum stress of Model-C reached 11.27 MPa.

\subsection{Discussion}

Corrosion expansion cracking susceptibility is dependent on the stress on concrete cover. Once the RC structure in marine environment cracks, chloride ions can reach directly the surface of the steel reinforcement, in which case, the reinforcement will corrode further. Under the coupled chemo-mechanical action, the stress on the concrete cover is higher than is the case under chloride attack alone. The degree of corrosion is increased by the coupled action, which can lead to a more severe cracking of the concrete cover. The FEA results were consistent with the experimental results noted earlier in this paper.
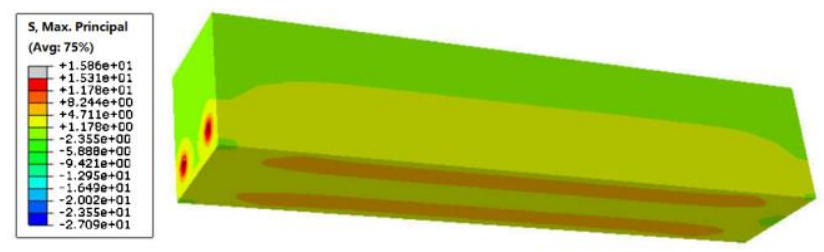

a
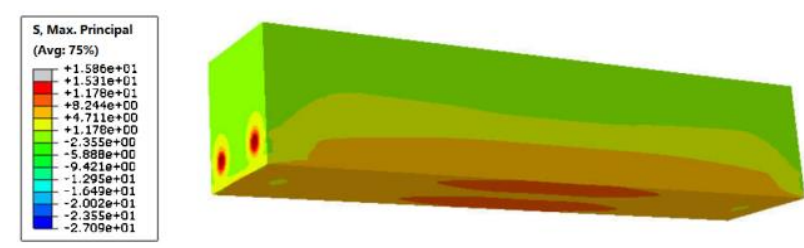

b

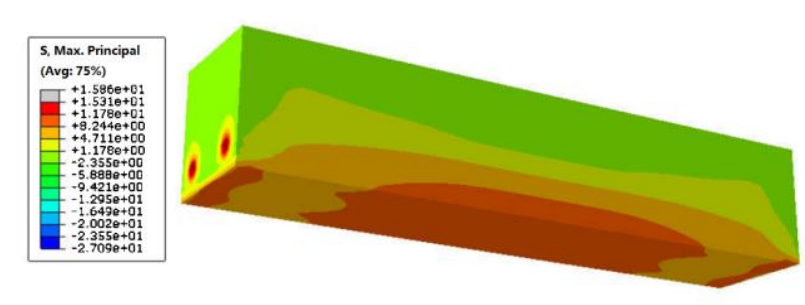

c

Fig. 9. Stress nephogram obtained from FEA based on Table 5: a-Model-A; $\mathrm{b}$-Model-B; c-Model-C

\section{CONCLUSIONS}

This paper has presented the findings of an investigation into the coupled effects of chloride ion ingress and static loading on the corrosion of steel reinforcement bars. A new accelerated corrosion test was adopted to simulate the non-uniform corrosion of steel reinforcements in concrete. The experimental results showed that the presence of a static load affected the halfcell potential and the degree of corrosion degree on the steel reinforcement. Tensile stress can make the steel reinforcement more prone to corrosion. Owing to the coupled action of carbonation and static loading, the nonuniform distribution of corrosion damage increased significantly with increase in the applied load.

A finite element analysis model indicated that the thermal expansion method was suitable to simulate the effect of oxide jacking due to rust formation. The presence of a static load increased significantly the maximum stress on the concrete cover, which increased the susceptibility of the concrete cover to cracking due to corrosion product formation. The FEA results were consistent with the laboratory test results obtained during this study.

\section{Acknowledgments}

The authors wish to acknowledge the financial support of "National Natural Science Foundation of China (Grant No. 51778577)" and "Zhejiang Provincial Natural Science Foundation (Grant No. LY15E080025)".

\section{REFERENCES}

1. Pei, X., Noël, M., Fam, A., Green, M. Development Length of Steel Reinforcement with Corrosion Protection Cementitious Coatings Cement and Concrete Composites 60 2015: pp. 34-43. https://doi.org/10.1016/j.cemconcomp.2015.04.003

2. Ou, Y., Nguyen, N.D. Influences of Location of Reinforcement Corrosion on Seismic Performance of Corroded Reinforced Concrete Beams Engineering Structures 126 2016: pp. 210-223. https://doi.org/10.1016/j.engstruct.2016.07.048

3. $\mathbf{X u}, \mathbf{Y}$. The Corrosion Characteristics and Tensile Behavior of Reinforcement under Coupled Carbonation and Static Loading Materials 8 (12) 2015: pp. 5479. https://dx.doi.org/10.3390/ma8125479

4. Zhao, Y., Dai, H., Jin, W. A Study of the Elastic Moduli of Corrosion Products Using Nano-Indentation Techniques Corrosion Science 65 2012: pp. 163-168. https://doi.org/10.1016/j.corsci.2012.08.016

5. Zhao, Y., Zhang, X., Ding, H., Jin, W. Non-Uniform Distribution of a Corrosion Layer at a Steel/Concrete Interface Described by a Gaussian Model Corrosion Science 112 2016: pp. 1-12. https://doi.org/10.1016/j.corsci.2016.06.021

6. Khan, I., François, R., Castel, A. Prediction of Reinforcement Corrosion Using Corrosion Induced Cracks Width in Corroded Reinforced Concrete Beams Cement and Concrete Research 56 2014: pp. 84-96. https://doi.org/10.1016/j.cemconres.2013.11.006

7. Rodriguez, J., Ortega, L.M., Casal, J., Diez, J.M. Corrosion of Reinforcement and Service Life of Concrete Structures Proceedings of the 7th International 
Conference on Durability of Building Materials and Components, Routledge, London, 1996 pp. 117-126.

8. Vidal, T., Castel, A., Francois, R. Analyzing Crack Width to Predict Corrosion in Reinforced Concrete Cement and Concrete Research 34 (1) 2004: pp. 165-174. https://doi.org/10.1016/S0008-8846(03)00246-1

9. Zhang, R., Castel, A., Francois, R. Concrete Cover Cracking with Reinforcement Corrosion of RC Beam During Chloride-Induced Corrosion Process Cement and Concrete Research 40 (3) 2010: pp. 415-425. https://doi.org/10.1016/j.cemconres.2009.09.026

10. Chen, E., Leung, C.K.Y. Finite Element Modeling of Concrete Cover Cracking Due to Non-Uniform Steel Corrosion Engineering Fracture Mechanics 134 2015: pp. $61-78$. https://doi.org/10.1016/j.engfracmech.2014.12.011

11. Guzmán, S., Galvez, J.C., Sancho, J.M. Modelling of Corrosion-Induced Cover Cracking in Reinforced Concrete by an Embedded Cohesive Crack Finite Element Engineering Fracture Mechanics 93 2012: pp. 92-107. https://doi.org/10.1016/j.engfracmech.2012.06.010

12. Du, X., Jin, L., Zhang, R. Modeling The Cracking of Cover Concrete Due to Non-Uniform Corrosion of Reinforcement Corrosion Science 89 2014: pp. 189-202. https://doi.org/10.1016/j.corsci.2014.08.025.

13. Jin, L., Zhang, R., Du, X., Li, Y. Investigation on the Cracking Behavior of Concrete Cover Induced by Corner Located Rebar Corrosion Engineering Failure Analysis 52 2015: pp. 129-143. https://doi.org/10.1016/j.engfailanal.2015.03.019

14. Xu, Y., Qian, C. Influence of Coupled Chemo-Mechanical Process on Corrosion Characteristics in Reinforcing Bars
Journal of Wuhan University of Technology - Materials Science Edition 28 (3) 2013: pp. 538-543.

15. Zhang, H., Zhao, Y. Performance of Recycled Concrete Beams Under Sustained Loads Coupled with Chloride Ion $\left(\mathrm{Cl}^{-}\right)$Ingress Construction and Building Materials 128 2016: pp. $96-107$. https://doi.org/10.1016/j.conbuildmat.2016.10.028

16. Xia, J., Jin, W., Li, L. Shear Performance of Reinforced Concrete Beams with Corroded Stirrups in Chloride Environment Corrosion Science 53 (5) 2011: pp. $1794-1805$. https://doi.org/10.1016/j.corsci.2011.01.058

17. Kim, Y.Y., Kim, J.M., Bang, J., Kwon, S. Effect of Cover Depth, W/C Ratio, and Crack Width on Half-Cell Potential in Cracked Concrete Exposed to Salt Sprayed Condition Construction and Building Materials 54 2014: pp. 636-645. https://doi.org/10.1016/j.conbuildmat.2014.01.009

18. Elsener, B., Andrade, C., Gulikers, J., Polder, R., Raupach, M. Hall-Cell Potential Measurements - Potential Mapping on Reinforced Concrete Structures Materials and Structures 36 (7) 2003: pp. 461-471.

19. Mancini, G., Tondolo, F., Iuliano, L., Minetola, P. Local Reinforcing Bar Damage in RC Members Due to Accelerated Corrosion and Loading Construction and Building Materials 69 2014: pp. 116-123. https://doi.org/10.1016/j.conbuildmat.2014.07.011

20. Ortega, N.F., Aveldano, R.R. Analysis of Concrete Beams During the Corrosion Process on Reinforcement Under Tensile Stress Open Construction \& Building Technology Journal 2 (1) 2008: pp. 243-250. 